\title{
景観設計プロセスにおける代替案選定手法に関する考察 \\ TECHNIQUE FOR ALTERNATIVE SELECTIONS OF A LANDSCAPE DESIGN PROCESS
}

\author{
本間里見*, 位寄和 久**, 両角光男**, 伊勢良一*** \\ Riken HOMMA, Kazuhisa IKI, Mitsuo MOROZUMI \\ and Ryoichi ISE
}

\begin{abstract}
In the designing process of an architectural project by a team, the designers should advance the design while continuously evaluating the work and making decisions as a group about the project. There are many situations in which two or more alternative solutions are selected by designers. The design team has adopted the decision making process based on strong opinions or majority vote. These methods sometimes faster unclear decisions which are not objective, and therefore, insufficient. To solve this problem, the author proposed the selection technique for alternative design solutions, in which Analytic Hierarchy Process by Saaty was applied. The subjective judgement of each evaluator was reflected in the selection of the alternative solution. By this technique, the decision process could be represented clearly and convincing. In this research, three models of alternative selection by AHP were compared and the effectiveness of each was confirmed.
\end{abstract}

Keywords : Analyitic Hierarcy Process, Landscape Evaluation, Consensus Desision Making

階層分析法 (AHP)、景観評価、合意形成

\section{1. 研究の背景と目的}

発電所建設など都市景観に影響を及ぼす大規模プロジェクトに 際し、建物完成後の景観予測と評価を計画段階で把挃し、設計に反 映させることは、良好な都市景観を形成していく上で重要である。 近年、地域と協調した計画が求められる都市景観のデザインは、地 域住民、行政などの様々な主体と合意を形成することは必然であ り、複数の関倸主体間における景観設計案の評価手法及び複数の代 替案からの選定手法が設計者から求められている。しかし、現状の 景観設計においては、意思決定過程が明確で合理的な選定手法がと られることは少ない。代替案選定の際に多数決により単純集計的に 結果が導かれたり、発言力の強い関係者の意見がそのまま採用され るなど不透明な決定プロセスが多い。既往の研究では、協調設計や 建築設計におけるプロセスの研究文献1 女献2 はみられるが、景観設計 のプロセスに関する研究は少ない。さらに、計画プロセスにおける 選定手法に関しては、色彩やシステムの選定手法に関する研究文新》 文胡1)はみられるが、計画者グループ注11における計画案の選定手法 に関する研究はない。また、近年、景観評価はCGを利用することが 一般的となったが㣮5) 文献6)、作成された代替案の具体的な選定ツー ルは提案されていない。今後のコンピュータによる景観設計支援の 方向性として、より多くの関係者が設計段階から参加し、評価と修
正を繰り返しながら設計を行うことは、良好な景観を創造する上で 重要となってきている就》。そこでは、効率的で透明性のある代替 案の選定プロセスが求められている。このため、本稿では、階層分 析法文䌾）注2)（以後AHPと呼ぶ）を用いた代替案選定モデルを提案 し、計画者グループによる景観設計におけるモデルの有効性と課題 を明らかにすることを目的とする。なお、本論文は、情報システム 利用技術シンポジウム（第21回、第22回）で報告したAHPを用いた 代替案選定システム献9) 文献10)によるケーススタディの結果に基づ き、さらに手法の検討を発展させ、異なる評価傾向を有する計画者 グループ間の合意形成支援を目的とした代替案選定モデルの提案に 関するものである。

\section{2. 研究の方法}

本研究では、まず、景観設計プロセスにおける代替案選定の場面 を抽出するために某火力発電所景観設計を事例として代替案選定プ ロセスをレビューした注3)。次に、AHPを用いた代替案選定モデル I を提案し、都市近郊に立地する清接工場注4) の景観設計における代 替案選定をケーススタディとして、この選定モデルの有効性と課題 を考察した。この選定モデル I では、評価項目が互いに独立してい ることを前提とした。しかしながら、景観評価では必ずしも評価項

\footnotetext{
* 能本大学工学部環境システム工学科 助手

** 熊本大学工学部環境システム工学科 教授・工博

*** ハウスプラス住宅保証侏）常務取䋨役
}

Research Assoc., Dept. of Architecture, Faculty of Engineering, Kumamoto University

Prof., Dept. of Architecture, Faculty of Engineering, Kumamoto University, Dr. Eng.

Executive, Houseplus Housing Warranty Corporation Limited 
目間の独立性が保証されない場合も想定される。そのため、評価項 目間に従属関保を認めるようにAHP を抬張した内部従属法を用いた 選定モデル II 及び評価構造のレベル注5)間に従属関係を認める外部 従属法を用いた選定モデルIIIを提案した。3つの選定モデルを比較 するため、3つの選定モデルを適用して景観評価を行った。この

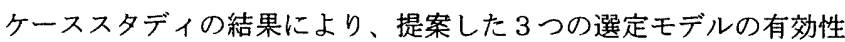
と課題を明らかにする。

\section{3. 代替室選定の場面}

公共性の高い大規模な施設建設における景観設計プロセスには、 複数の関倸者がプロセスの様々な場面でデザインの合意を形成して いかなければならない。このようなプロセスにおいては、設計案の 客観性と透明性を高めるために複数の設計案を用意し、関係者間で の検討により代替案が選定されることが多い。ここで、実際の設計 業務においてどのような場面で設計案の選定が行われるのかを見る ため、某火力発電所の設計プロセスをレビューした。検討された代 替案は、タービン建屋、ボイラー建屋、煙突、タンク群等の色彩、 色の塗り分け、煙突の形状、煙突の先端部分に塗装される「はちま き」の色彩に関して組み合わせによりヴァリエーションが考えられ た。検討資料として、各代替案モデルのCG 画像を現地写真に合成 した画像が用意された。代替案は各プロセスごとに修正されて増減 するが、代替案を絞り込む場面（案の数が減少する）に注目し、複 数の選定シーンを抽出した。これらの選定シーンでは、以下のよう な特徴が見られる。

(1)共通の評価基準を設定して選定したのではなく、各個人の評価 基準により順位づけされた

(2)決定には単純集計による多数決が採用された

(3)個人の評価はすべて平等に扱われた

ここで問題になるのは、以下の点である

(1)評価項目が設定されないかもしくは設定されても項目の重要度 が一律として評価される

(2)集団において、単純集計による選定順位の決定には、どれだけ 個人の評価が影響したのか捉えられない

(3)代替案を絶対評価として採点することは、景観評価のもつ曖昧 性から被験者の負担となる

(4)単純集計による多数決では、選好順位に妥当性がない

この 1 つの事例で、代替案選定の場面をすべて抽出できたわけ ではないが、少なくとも評価者それぞれの意見が反映され、かつ集 団における透明性のある選定プロセスを示す手法が求められている ことが明らかになった。グループ作業でよく採用される多数決原理 は、個人の判断にあたっては妥当な選考順位の推移律が、必ずしも グループの推移律を満たさないことがある。グループの意思決定に おいて、多数決は本質的に矛盾を孕むことをアロウ就い）が示唆し ているように、現状では計画者グループでの意見を統一する有効な 手段がない。このため合意形成を目的とすると、計画者グループ内 の意見が一意に定まらなくても、意見によるメンバーの傾向、選定 に至るまでのプロセスを明らかにすることが重要な条件となる。

景観計画における従来の代替案選定手法がもつ上記(1) (4)の問 題点に対応でき、数学的根拠を有する意思決定モデルであるAHPを 選定手法として提案する。

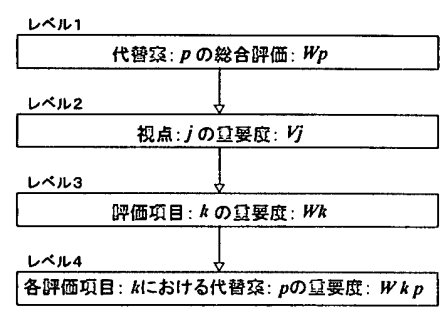

表 1 一対比敦における垔要度の尺庶

\begin{tabular}{|c|c|}
\hline 至要虚の尺度 & 定国 \\
\hline 1 & 同程度に互要 (EQUAL) \\
\hline 3 & やや要(WEAK) \\
\hline 5 & かなり直要(STRONG) \\
\hline 7 & 非常に箸要(VERY STRONG) \\
\hline 9 & 挃めて醘要(ABSOLUTE) \\
\hline
\end{tabular}

图1 景㽙鲜価の評価轵造

\section{4. 代替案選定モデル}

\section{1. 階層分新法の適用}

AHPを用いた景観評価では、まず、選定プロセスの階層構造を作 成する。ここでは、階層構造を以下の 4 つのレベルで構成する。す なわち、総合評価 (レベル 1) 一視点の重要度 (レベル 2)－評価項 目の重要度 (レベル 3 ) 一代替案 (レベル 4 ) で構成される(図 1)。 選定の方法は、以下の作業手順で行う。

i ）景観評価を行う視点の重要度を以下の手順で決定する。 (1)視点選定条件の一対比較を行い一対比較行列を作成する。 (2)その行列の固有べクトルを計算注6) し、選定条件の重み係数を 決定する

(3)各条件からみた視点候補の重み倸数を評価する

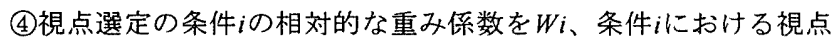
$j の$ 重み係数を $X i j$ とすると、視点 $j$ の重要度 $V j$ は、次式で求めら れる

$$
\begin{aligned}
& V j=\sum\left(W_{i} \cdot X i j\right) \\
& \text { ただし、 } \sum W i=1 \quad(i=1,2,3 . . \text { 条件の綵数 })
\end{aligned}
$$

ii ) 評価項目の重要度の決定

(1)評価項目 $k$ を一対比較し、一対比較行列を作成する

(2)行列の固有ベクトルを計算し、評価項目の重み係数 $W k$ を求める

iii）各評価項目における代替案の重要度の決定

(1)評価項目 $k$ において、代替案 $p$ の一対比較行列を作成する

(2)行列の固有ベクトルを計算し、各評価項目における代替案の重 要度 $W k p$ を決定する

iv）すべての視点からの全評価項目における代替案の総合評価 (1)視点 $j$ の重要度を $V j$ 、評価項目 $k$ における代替案 $p$ の重要度を $W k p$ とすると、代替案 $p$ の総合重要度 $W p$ は、次式で求められる

$$
\begin{aligned}
& W p=\Sigma\left(V_{j} \cdot \Sigma W k p\right) \\
& \text { ただし、 } \Sigma V_{j}=1 \quad(j=1,2,3 . . \text { 視点の新数) }
\end{aligned}
$$

ところで、AHPでは、一詨比較が首尾一貫していることが必要で あり、その整合性を判断する指標として整合度 CI (Cons is tency Index) を用いる。整合度 $C I$ は、最大固有ベクトルを $\lambda$ max、項目 数を $n$ とすると、

$$
C I=(\lambda \max -n) /(n-1)
$$

で求められる。CIが0.1以下で整合性のとれた評価值である。

\section{2. 選定テデル I}

景観計画におけるAHP を用いた代替案選定プロセスを、4レベ ルの階層構造を持つモデルで示した。この階層構造に従って選定 の作業モデルを考える。作業モデルは、景観評価を行う視点の重要 度を決定する部分と景観計画案の重要度を決定する部分の二つに 


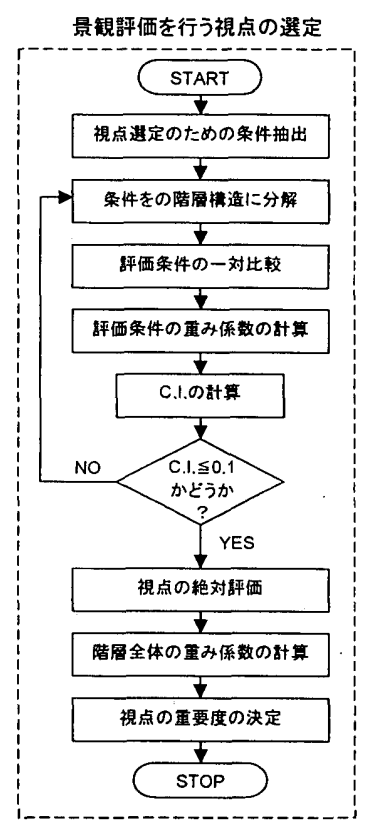

图 2.a 視点選定モデル

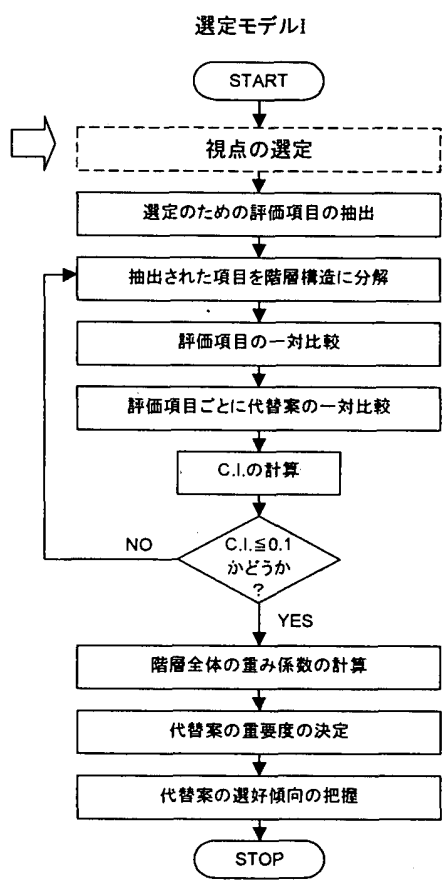

图 2.b 代替案選定モデル
表 2 呯価項目（基準）の内容

\begin{tabular}{|c|c|}
\hline 諲価項目（基準） & 評価内容 \\
\hline 背暴（遠景）との的和 & $\begin{array}{l}\text { 環境工場の背量となる山並み、町並み、田園風景などと調和 } \\
\text { している度合い }\end{array}$ \\
\hline ランドマーク & 煙突がランドマークとして捉えられる度合い \\
\hline 地域性があるか & 地域の特性が外钼に反映されている度合い \\
\hline 清掦エ場らしくない & 一般的な潧担工場らしく見えない度合い \\
\hline 周辺 (近景) への配虞 & 剩地に隣接する地区の景钼に調和している度合い \\
\hline 旧施殷への対応 & 隣接する旧施殷とデザインが調和している度合い \\
\hline
\end{tabular}

分けることができる。視点の重要度を決定することは、景観評価に とって前提条件となる作業である。ここでの想定される視点の評 価基淮は、プロジェクト毎に話し合いで決定されることを想定し ているが、距離などの定量的な指標と文化性、景観的価值といった 定性的な指標を同時に用いるため、AHP は有効である。また、視点 の候補は、かなりの数にのぼることが予想されるため、評価者の主 観的判断にのみ基いて、一対比較すると整合性がとれない。この問 題を解決するため、絶対評価法（AM 法）注7)を適用する。視点選定 モデルを図 2.aに示す。

代替案の選定プロセスでは、選定のための評価項目を話し合いの もとに決定するところから始まり、階層構造の決定、評価項目の一 対比較、各評価項目から見た代替案の一対比較、代替案の総合重要 度の計算、そして各代替案の選好傾向の分析と進む。この代替案選 定のための作業モデルを選定モデル I （図 2，b）として提案する。 この選定モデル I は、評価項目が相互に独立していることを前提 条件とした AHP の基本モデルである。なお、選定モデルで用いられ る一対比較における重要度の尺度基準は、表 1 に示すとおり、 5 段 階評価とする。

\section{5. ケーススタディ}

\section{1. 目的と方法}

実際の景観計画における、AHP を用いた選定モデルの有効性と問 題点を明らかにするため、熊本市郊外に立地する熊本市東部環境 工場（清掃工場）の基本計画をテーマにケーススタディを行っ

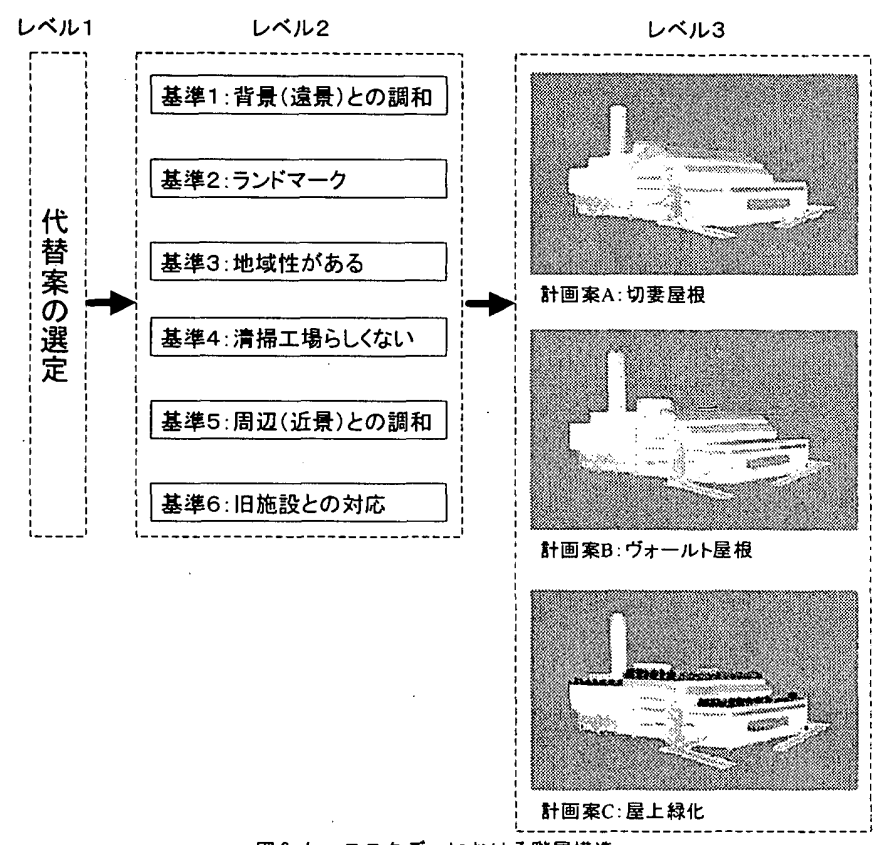

图 3 ケーススタディにおける階廨構造

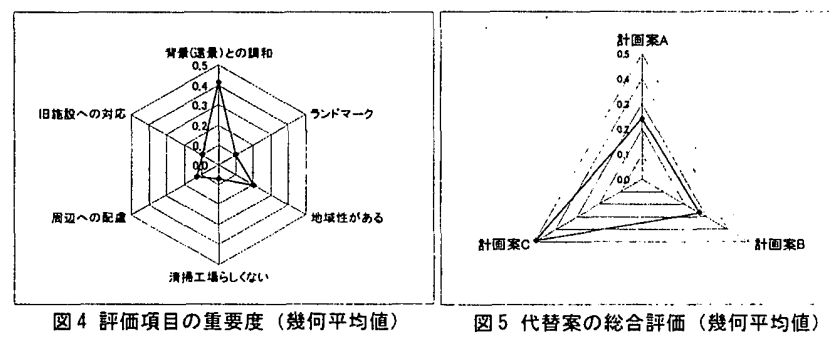

た。基本設計段階において、周辺景観との調和を考慮して、計画者 グループが複数案から 1 案を選定する場面を想定した。ケーススタ ディでは、実際に建設されている案に代替 2 案を加え、3 案から 1 案を計画者グループに選定させた。代替案の計画規模（SRC5 階建， 延床面積 $24.000 \mathrm{~m}$ ，煙突高さ $80 \mathrm{~m} ）$ はすべて同等とし、屋根と煙突先 端部の形状を変化させた。大規模施設計画の場合、この屋根と煙突 の形状が周辺の景観に影響を与える重要な要素の一つと考えた。計 画案 A は切妻屋根案、計画案 B はヴォールト屋根案、計画案 C は屋 上緑化案とした（図 3 )。計画者グループは、景観計画に携わる建築 プロフェッショナルと学生あわせて 10 人が、景観評価システム峬9) を使って代替案を選定した。評価に用いた画像は、奏写の背景とCG モデルを合成したものである。画像サイズは、400×300 ピクセル とした。なお、このケーススタディでは、図 2 . a の視点選定モデル を利用し、施設全体の眺望を確保できる近景・中景・遠景社8)の代 表視点を抽出し、そこからの評価を行った社9!。

代替案を選定するための評価項目として、計画コンセプトや地域 特性を考虑し、計画者グループによって表 2 の 6 項目（背景との調 和/ランドマーク／地域性がある/清掃工場らしくない/周辺へ の配慮／旧施設への対态）がブレインストーミングによって決定 された。この評価項目は一般的ではないが、個々の計画には独自の 選定基準があると考えられ、計画者グループによる評価項目を採 用する必要がある。AHPにおけるこの代替案選定の階層構造を図 3 に示す。レベル 1 は、最適案の選定であり、レベル 2 は 6 つの評価 項目であり、レベル 3 は、選定される代替案である。一対比較の重 
要度の尺度は表 1 に示すとおり 5 段階とした。また、計画者グルー プの值をまとめるために、幾何平均法10) を用いた。

\section{2. ケーススタディの結菆}

代替案の総合評価を算定するために、選定モデル I を適用した 結果を述べる。この計画者グループの代替案選定における評価項 目の重要度を図 4 に示す。「背景（遠景）との調和」が、0.411 と 高いウェイトを示した。その他の項目は「地域性がある」が若干高 いが、ほほ同程度のウェイトを示した。この結果、この計画者グ ループは、評価の際に「背景（遠景）との調和」を特に重要視した ことがわかる。次に、代替案の総合評価を図 5 に示す。屋上緑化の 計画案C が 0.493 と高いウェイトを示し、ヴォールト屋根の計画 案 B が 0.268 、切妻屋根の計画案 A が 0.240 と同程度のウェイトを 示した。結果的に、計画案 $C>$ 計画案 $B>$ 計画案 $A$ の順に選定され ることになるが、計画案 C と他の 2 案の差は大きい。選定モデル I を適用することで、この評価グループの選定基準の傾向及び各代 替案の選好傾向が明らかになった。

\section{3. 選定そデルIの有勃性と問題点}

ケーススタディ終了後、参加した評価グループに結果について ヒアリングを行った。選定モデルIを代替案選定に適用した場 合、従来の選定方法に比べ以下のような利点があげられた。 (1)計画者グループ全体の評価項目の重要度がわかる

(2)代替案選定の順序だけではなく、各代替案の選好における定性 的な評価が把握できる

(3)一対比較による代替案の評価は、点数による評価に比べ、評価 者の判断時の精神的負担を軽減した

また、以下の問題が指摘された。

(1)評価項目において個人の代替案の評価值にばらつきがある (2)評価項目の独立性が保証されない場合の対処ができない (3)評価項目の解勫に個人差がある

\section{6. 搪張階層分析法の適用モデル}

\section{1. 要素間に従属性がある場合}

AHP 法で代替案の重要度を決定する時は、二つの独立条件を仮 定している。一つ目の条件は、同一レベルにある要素は互いに独立 していること。二つ目の条件は、異なるレベルにある要素は互いに 独立していることである。ところが、グループ内での話し合いによ り決定される評価項目は、必ずしも独立性を意識して決定される ものではない。また、評価項目の重要度においても評価者それぞれ が、異なるイメージを持って一対比較している可能性も大きい。こ のような場合、Saatyは、内部従属法及び外部従属法とよぶ拡張AHP を提案している媩12)。内部従属法は、同一レベルにある要素間にお いて従属性がある場合、その関係性を考虑して各要素の重み係数 を修正する。外部従属法は、異なるレベル間の要素間において従属 性がある場合、下位レベルの要素に対する上位レベルの要素の重 み係数を算定し、上位レベルの要素の重み係数を修正する。

\section{2. 選定そデル II}

内部従属法では、各評価基淮の間及び各代替案の間に従属関係
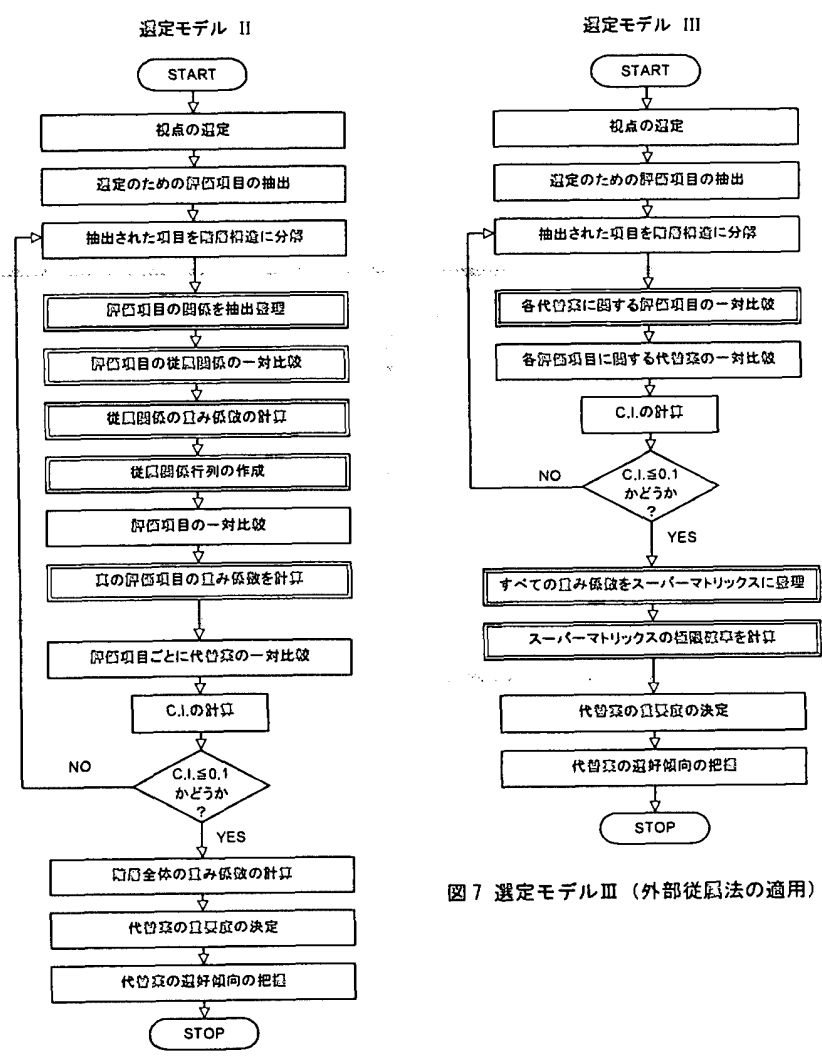

图 7 選定モテルIII（外部従居法の適用）

图 6 選定モデルII（内部従目法の適用）

を包含している。印象評価による代替案の選定には、評価項目が互 いに関係をもつ場合が多い。例えば、熊本の場合、阿蘇の山並みが 地域にとって重要な景観資源であるため、評価項目の「背景 (遠景) との調和」と、「地域性ある」は、互いに関係があると予想される。 しかし、この関係を示す客観的な指標が得られない場合、評価者の 価值観に頼らざるを得ない。内部従属法はこの評価者の主観によ る評価項目間の関連の強さを一対比較で算定して当該の従属関係 を定量的に内包するモデルである。この内部従属法を応用した代 替案選定作業モデルを選定モデル II（図6）とする。評価項目間の 関連度を求めるには、まず、ある評価項目に対し他の評価項目が影 響している強さの一対比較行列を作成し、その固有ベクトルを求 める。各項目について求められた固有ベクトルをまとめた、評価項 目間の従属関係行列 $M$ とする。ここで、選定モデル I における評価 項目の重要度をWとすると、真の重要度 $W^{\prime}$ は、次式によって求め られる。

$$
W^{\prime}=M \circ W
$$

こうして求められた真の重要度を用いて代替案の総合評価を求め る。代替案の総合評価の算定は、選定モデル I に準ずる。

\section{3. 選定モデルIII}

一方、異なるレベル間の要素に関係性がある場合、つまり代替案 ごとに評価項目の重みを変えたいような場合は、外部従属が適用 できる。例えば、ケーススタディにおける計画案 A 及び計画案 $\mathrm{B} と$ 計画案 C では、屋根形状の違いと屋上緑化を同時に比較するため、 被験者の持つ価值観が大きく異なる可能性がある。このような場 合、評価項目の重要性を決定する上で、代替案の存在を考虑する必 要がある。この外部従属法を応用した代替案選定プロセスを選定 


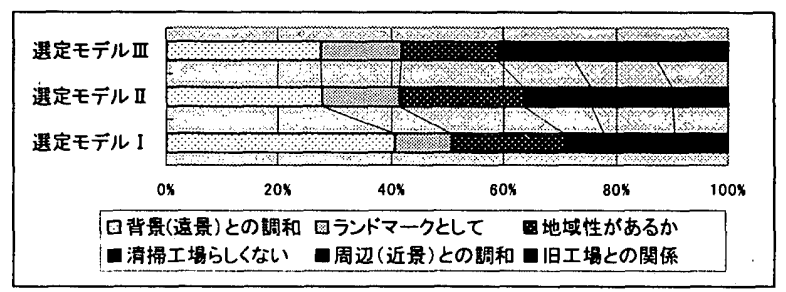

图83つの選定モテルルよる鲆洒項目の重みの比较

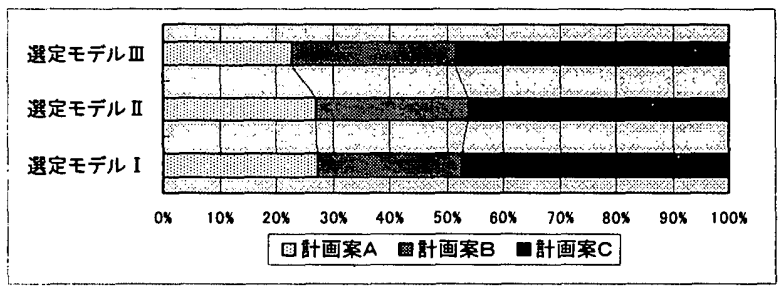

图 9 3つの選定モテルによる総合訐価の比皎

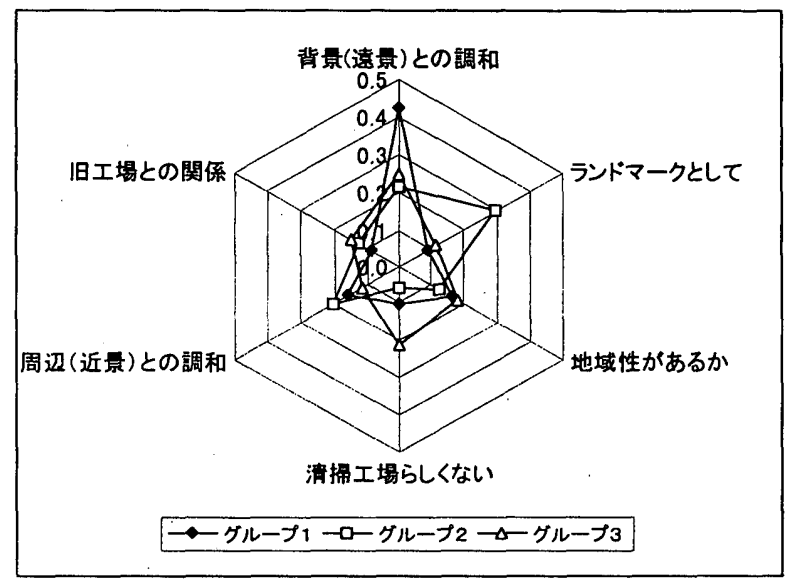

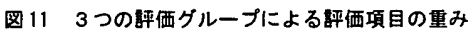

モデルIII（図 7) とする。選定モデル亚における評価項目の重要度 の計算は、各代替案ごとの評価項目の重要度および、各評価項目に おける代替案の重要度を同時にSuperMatrix 文献12) 注11) と呼ばれる行 列に表す。この行列は、マルコフ連鎖になっているので、この極限 確率を計算すると、評価項目の重要度と代替案の重要度が同時に 求まる。

\section{4.ケーススタディにおける選定モデルの比較}

提案した $3 つ の$ 選定モデルを比較するために、前述のケースス タディにおいて、拡張A H P を利用した景観評価システム献10)を用 いて、それぞれのモデルを適用した結果を比較する。既に述べた ようにケーススタディに用いられた評価項目は、計画者グループ のメンバーがコンセプトを話し合い、想定したものであり、評価 項目間で相互に影響を与える可能性がある。また、既知の代替案 を評価する場合、評価項目の重要度決定の際に、代替案の影響を 受ける可能性も考えられる。ここで、評価項目の重要度に関して

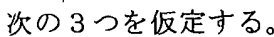

仮定 1 ) 各評価項目が互いに独立、重要度が一意的に決定 仮定 2 ) 各評価項目が互いに従属、重要度が一意的に決定

仮定 3 ) 各評価項目が互いに独立、重要度が各代替案で異なる 仮定 1）では、選定モデル I を適用する。仮定 2)では、選定モデ ルII を適用し、仮定 3 ）では、選定モデルIII適用する。これら 3

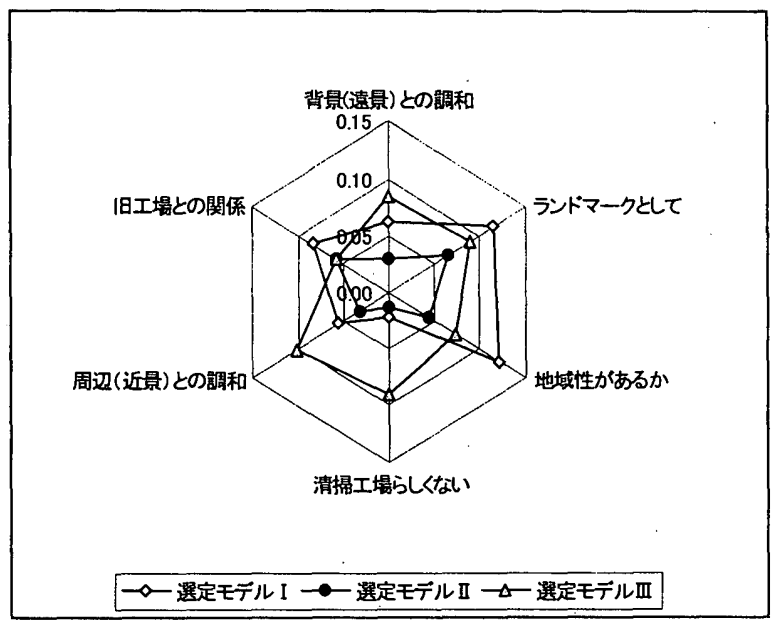

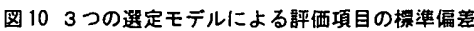

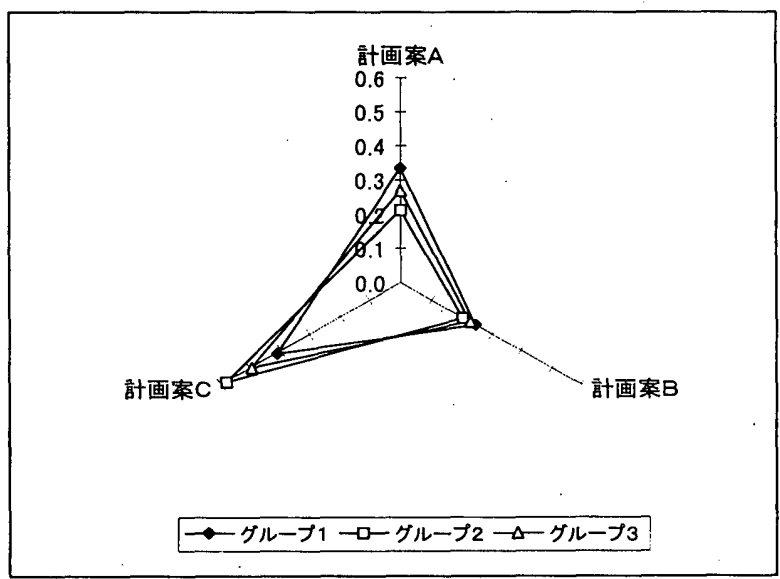

图 $123 つ の$ 評価グループによる棇合話価

つの選定モデルを適用し、計算された評価項目の重みを図 8 に示 す。この重みの算定は、10人評価者の幾何平均をとった。6つ の評価項目の重みの順位は、3つのモデルとも大きく変わらない が、「背景（遠景）との調和」に関しては、選定モデルIのみ大き な值となった。これは、この項目が他の項目に大きく影響されてい ることを示している。また、代替案の総合評価は、図 9 に示すとお り、3つのモデルのいずれも計画案 Cの評価が高く、評価值の比率 もあまり変わらなかった。つまり、このケーススタディでは、評価 項目の重要度が変わっても総合評洒にはあまり影響がなかったと いえる。

\section{7. グループの評価分析}

ケーススタディでは、3つの選定モデルを適用してその結果を 比較したが、計画者グループ全体の意見を集約するために、10人 の幾何平均值を用いて評価の分析をおこなった。ここでは、個人の 評価のばらつきに着目して、3つの選定モデルを比較する。図 10 は、3つの選定モデルにおける評価項目ごとの評価值の標準偏差 を示したものである。明らかに、選定モデル IIでは、各項目のばら つきが少ないことがわかる。つまり、内部従属法を適用すること で、評価項目間の関連性が考慮され、重要度への個人差の影響が減 少する。モデルI とモデル价を比較すると異なる項目でばらつき が大きくなっている。これは、評価項目のもつ言葉のイメージのみ 
で、重要度を決定するモデルI と具体的な代替案を意識しながら 決定をおこなうモデル而の違いを示している。「ランドマーク」や 「地域性がある」といった項目は、具体的な代替案が与えられるこ とにより評価基準が明確になると考えられる。

評価者の傾向については把握できるであろうか。そこで、モデル IIIの結果を用いて、評価者のクラスター分析 (Word 法, 平方ュー クリッド距離）をした結果、大きく3つのグループに分かれた（図 11 )。グループ1は「背景（遠景）との調和」を重視するタイプ。 グループ2は、「周辺 (近景) との調和」と「ランドマーク」を重 視するタイプ。グループ 3 は、「背景（遠景）との調和」と「清掃 工場らしくないを重視するタイプである。この3つのグループの 評価項目の重要度を用いて総合評価した結果を図 12 に示す。総合 評価では、3つのグループ間で大きな差はみられない。このことか ら、総合評価としてしてはまとまってみえるが、メンバーのあいだ で、重要視している評価項目が異なっていることがわかる。計画者 グループでの意思決定の場面では、結果はもちろん重要だが、その 決定過程でどのような指向を持ったメンバーが集まり、どのよう に結果に反映されたかを明らかにすることは重要である。その意 味において、この選定モデル而は計画者グループの意思決定にお いて、有効であることがわかる。

\section{8. まとめ}

本稿では、景観計画プロセスにおける代替案の選定手法をテー マとして、計画者グループのための AHP 手法を応用した選定モデル を提案した。ここでは、選定条件の違い、寸なわち、選定条件が互 いに独立していると仮定できる場合、同レベルの選定条件に従属 関俰がある場合、代替案ごとに選定条件の重要度が異なる場合と いった選定条件の違いを考慮し、3つの選定モデルを提案した。さ らに、ケーススタディを行うことで、以下のように、この3つのモ デルの有効性と特徽の違いが明らかになった。

各モデルに共通する有効性：

(1)代替案の選定順位だけではなく、計画者グループの評価基準に 対する傾向や個人による評価值の違いが明らかとなる

(2)評価者は、代替案の選定において評価基準を作成するところか ら参加するため、決定に対する参加意識が向上する 特徵の違い：

(1)モデルIでは、従属性の高い評価項目が含まれる場合は問題が ある。一対比較の数が少なく評価者の負担は小さい

(2)モデルIでは、評価項目間に従属性があっても整合性に問題は ない。一対比較の回数が増え、評価者に負担がかかる

(3)モデルIIIでは、評価項目の重要度を一意的に決定するのではな く、代替案ごとに評価項目の重要度をかえることができるため、 より評価者の意思を反映する。一対比較数は增加する

これらの選定モデルは、場合により使い分ける必要がある。評価 項目が独立していると考える場合、簡便なモデル I を適用する。ま た、評価項目間の関倸性を把握した上で評価したい場合は、内部従 属法を使うモデル II を、代替案のコンセプトが大きく異なり、評価 項目の重要度を一律に適用できないときは、モデル吕を利用する。 これらの選定モデルを適用することで、代替案の選定プロセスが 透明化され、それにより合意形成の促進が期待できる。今後は、
様々なケーススタディを通して、より複雑な条件下で適用可能な 選定モデルとして改良していきたい。また、住民を含めた広節囲の 関係者が関与する景観計画においてもこれらのモデルが適用でき るよう発展させたい。

\section{謝辞}

本論文をまとめるにあたり、熊本市環境保全局及び、東部環境工 場建設担当者の皆様には、貴重なご意見と資料を提供していただ きました。ここに感謝の意を表します。

\section{参荅立触}

1) 北尾靖雅，内井昭蔵，宗本順三：マスターアーキテクト方式によるニュー タウンの協儌設計手法の研究一マスターアーキテクトの環境設計プロセス での調整行為と役割- 計画系論文集 No. 512, p. 183, 1998

2) Mitsuo Morozumi, Riken homma, W. Mitchell: The level of communications achieved through network in an international collaborative design project, Proceedings of The 2nd Conference of Computer Aided Architectural Design Research in Asia, pp.143-152, 1997

3）中山和美,佐藤仁人, 澤田敏実: ニューラルネットワークを用いた建物外観 色彩選定法の研究, 計画系論文集 No. 510, p. 9,1998

4）玄昌澤，全 文茜：AHPおよびLCC概念を利用した最適案選定システムの 開発一設備システムの選定を中心に, 計画系論文集 No. 469, p. 149, 1995

5）有馬隆文, 佐藤誠治, 萩島哲, 坂井猛, 趙世晨, 小林祐司：3次元 CG 考用い た景観特性の計量化とそのシステム開発に関する研究，計画系論文集 No. 523 , p. 227,1999

6) 西名大作, 村川三郎: 河川固観評価予測モデルの作成と適用性の検討 コンピュータ画像処理による河川環境評価に関する研究 その2, 計画系 論文集 No. 494, p. 61,1997

7) Riken Homma, Kazuhisa Iki, Mitsuo Morozumi: Network-Based Dynamic Evaluation Process For Urban Landscapes, Proceedings of The 3nd Conference of CAADRIA, pp.213-223, 1998

8）利根菩：ゲーム感觉意思決定法 AHP 入門 日科技連 1986，第 10 版 1997

9）本間里見, 位寄和久, 両角光男：AHPによる景観設計案の選定支援システ ムの開発一ネットワークを利用した景観計画の合意形成に関する研究一日本 建築学会第 21 回情報・システム・利用・技術シンポジウム論文集 pp. 349354,1998

10）本間里見, 位㟢和久, 両角光男：AHPによる景観設計案の選定支援システ ムの開発その 2 一ネットワークを利用した景観計画の合意形成に関する研究 一日本建築学会第 21 回情報・システム・利用・技術シンボジウム論文集 pp. 97-102, 1999

11）ケネス・J・アロー 著, 長名宽明 訳：社会的選択と個人的評価 日本経済 新閆社 1977

12) Thomas L. Saaty: The Analytic Hierarchy Precess, 2nd Edition, RWS Publications 1996

注歌

注1)ここでの計画者グループとは、複数の計画主体から構成されるグルーブを指 す。本論文では、このグループ内での合意形成の筑囲で検討を行う。

注2)T. L. Saatyにより開発された意思決定手法である。

AHP は、数理的意思決定法の中でも取り扱いやすい手法の一つであり、従来 の意思決定手法に比べて、複雑かつ構造の不明確な問題を構造化することに により整理し、多くの評価項目を取り入れることができる。AHPでは、一対 比較により、明確な尺度を持たない要素間の比率を曖昧に答えることを許容 するため、意思決定者の負担を軽くすることができる。また、この䁔昧さを 尺度として警合度を算定することによって、意思決定者の判断の整合性を保 ちながら評価を倠めることができる。そこで、近年、都市計画、景観保全な どの分野でAHPによる研究 (文献13)〜15) 参照)が数多く見られるように なった。具体的な手順は、以下に示す 3 段階からなる。

(1) 第一段階

公合的に影楖を及ぼす評価項目を列举し、評価の階層構造を構築する。階 绝の最上層は、総合目的であるが、それ以下のレベルでは複数の評価項目に 分解する。最下層は、直上の評価項目に関するデータのランク值で構成され る。

(2) 第二段階

各レベルを構成する評価項目の重み付けを行う。具体的には、一対比較法を 用いて上位の評洒項目に対する重要度を評価する。この一対比較に用いられ る重要度の評価值の定義は表1に示すとおりである。得られた各レベルの一 対比較行列から、各レベルの評価項目間の相対重要度を計算する。計算方法 は一対比較行列の最大固有值に対する正規化した固有ベクトルが各評価項 目間の相対重要度となる。なお、一対比較において意思決定者の答えは完全 な整合性を持つことは不可能であり、この暖昧さを評価する尺度として、整 合度 (C. I. ) が定義されている。

(3) 第三段階

各レベルの評価項目間の相対重要度から総合評価值を算出する。これによ り、総合目的に対する代替案の順位を決定する。

注3) 某火力発電所計画において、計画主体である電力会社の計画者グループが、 基本設計の段階で外装の色彩設計案を決定する際に行ったアンケートをもと に、代替案選定過程をレビューした。

注4)熊本市東部環境工場をもとに仮想の代替案を作成した。 
注5) AHP の階層構造において、各層をレベルと呼ぶ。

注6)一対比較行列の固有べクトルが、各要素の重みとなる。この固有べクトルの 計算は、利根㙵のBASICプログラム（文献 11 参照）を参考にEXCEL で稼動 するプログラムを作成した。

注 7)絶対評価法は、Saaty が提案したAbsolute Measurement Approachであ る。AM法とも呼ぶ。オリジナルのAHP法では、各評価基準に関する各代替案 の評価を各代替案の一対比較で行うが、AM法では、一対比較ではなく絶対評 価尺度を媒介にして、間接的に比較を行う。このAM法の利点として、以下の 項目が举げられる。(1)代替案が追加されたとき、再度代替案の一対比較をす る必要がない。(2)代替案が追加されたとき、代替案の順序が逆転することが ない。(3)代替案の数が増えても評価者の負担は増えない。本研究では、視点 老絞り込む際に、視点場の種類に上り5段階 視点場の施設利用者数により 3段階、対象までの距離により 3 段階で評点をつけ、AM法により選定視点の 重要度を決定した。

注8) ケーススタディでは、視点から対象までの距離が $0 \sim 0.5 \mathrm{~km}$ を近景、0.5km から $1.5 \mathrm{~km}$ までを中景、それ以上離れているところを遠景として扱った。

注9）自然景観豊かな地域における景観設計では、予め重要な視点が設定されてい ることが多いが、このケーススタディの場合、都市の郊外の特に観光名所と なる場所がない地域に立地する施設であり、絶対条件として評価が必要な視 点の想定はなかった。ケーススタディでは、半径約 $5 \mathrm{~km}$ 以内の梘点となりう る場所について、公共性、利用者数、評価対象からの距離を評価基準として、
40 視点候補から8視点に絞り込んだ。この結果を計画者グループで険討し 妥当なものと判断した。このためケーススタディでの視点選定はこのモデル を適用した。

注 10)幾何平均:

$\mathrm{k}$ 個の数值 $\mathrm{a} 1, \mathrm{a} 2$, ・ ・ an の幾何平均は数值の積の $\mathrm{k}$ 乗根で求められる。 $(\mathrm{a} 1 \mathrm{a} 2 \cdot \cdots \text { an })^{1 /}$ (5)

AHPをグループの意思決定に適用寸る場合、基本的には話し合いにより各評 価項目間の一対比較の評点を決定寸べきであるが、メンバーの考え方の違い に上り傾向が異なる場合があるこのような場合にグループとして1つの評 点を数学的にまとめる方法として一対比較行列の各要素をメンバーの評点の 幾何平均を用いる。この幾何平均は行列の対角要素 (逆数) は、メンバーの 評点の逆数の幾何平均に等しいためこの行列はAHPの計算が可能である。本

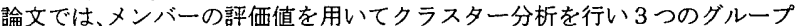
を設定した。その後、グループ内の評価值を幾何平均してグループの代表值 とした。

注 11)SuperMatrix とは、AHPにおける階層構造の異なるレベル間に従属性があ る場合にそれらの閐係を同時に表現する行列である。SuperMatrixは、外部 従属のAHPの計算の際に用いられ、評価基淮の各要素と代替案の各要素の関 係を 1 つ行列で表現する。この行列は、マルコフ連鎖になっており、その 極限確率を求めることで、各要素が一定の值(重み)に収束する。

（1999年11月10日原稿受理，2000年 7 月17日採用決定） 